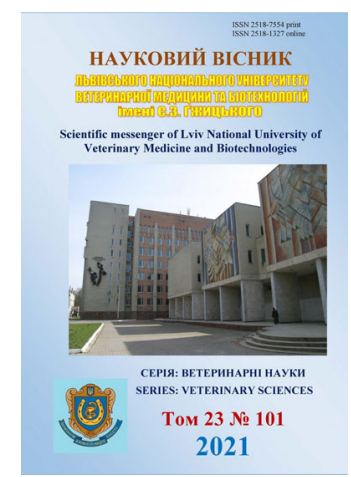

\author{
Науковий вісник Дьвівського націонадьного університету \\ ветеринарної медицини та біотехнодогій імені С.3. Гжицького. \\ Серія: Ветеринарні науки \\ Scientific Messenger of Lviv National University \\ of Veterinary Medicine and Biotechnologies. \\ Series: Veterinary sciences
}

UDC 577.181.7:598.1

\title{
Features of the usage of antibiotics in herpetology
}

\author{
W. I. Chuliuk
}

Stepan Gzhytskyi National University of Veterinary Medicine and Biotechnologies Lviv, Ukraine

Article info

Received 13.01.2021 Received in revised form 15.02 .2021 Accepted 16.02.2021

Stepan Gzhytskyi National University of Veterinary Medicine and Biotechnologies Lviv, Pekarska Str., 50, Lviv, 79010, Ukraine. Tel.: +38-096-275-51-26 E-mail:Slawakill96@gmail.com
Chuliuk, W. I. (2021). Features of the usage of antibiotics in herpetology. Scientific Messenger of Lviv National University of Veterinary Medicine and Biotechnologies. Series: Veterinary sciences, 23(101), 61-66. doi: 10.32718/nvlvet10111

The article summarizes the literature data on the frequency and causes of diseases of reptiles, the peculiarities of their infection with bacterial microorganisms, the use of antimicrobial drugs and the development of antibiotic resistance. It should be noted that the use of antibiotics and other antimicrobial drugs in veterinary herpetology has its own characteristics, due primarily to the peculiarities of thermoregulation and metabolism in reptiles, the nature of the pathogenic microflora inherent in these animals. In reptiles, infection with gram-negative microorganisms is more common: enterobacteria (salmonella, Escherichia coli, Proteus) and gram-positive bacteria (staphylococci and streptococci), as well as saprophytes belonging to the group of spore-forming microorganisms. Some species of actinomycetes show quite pronounced pathogenic activity as well. Reptiles suffer from salmonellosis or are salmonella carriers. In such cases, conditions are created for the potential infection of humans with salmonella, most often infecting children and the elderly who come into contact with sick reptiles. Other anthropozoonoses (eschiriosis, leptospirosis, chlamydia, campylobacteriosis, streptococcal and staphylococcal infections, fungal infections, etc.) are dangerous as well. Antibiotics were prescribed to sick reptiles "at the beginning" of the development of veterinary herpetology. The effectiveness of antimicrobial drugs depends on many factors (species, age and sex of reptiles, their physiological state: temperature, metabolic rate, the presence of underlying and comorbidities, the type of bacteria that infect reptiles and their resistance to antibacterial drugs, etc.). Unlike mammals, reptiles have a portal venous system of the kidneys, which is represented by a system of veins, through which much of the venous blood from the back of the body enters the portal vein of the kidneys, which breaks down into a system of capillaries isolated many toxic compounds, including antibiotics. Thus, the portal venous system of the kidneys, together with the portal venous system of the liver play an important role in the metabolism and excretion of most antibiotics. Taking into account the potential nephrotoxicity of antibiotics and the possibility of their rapid excretion from the body (due to the presence of the portal venous system of the kidneys), most herpetologists recommend parenteral administration of drugs to reptiles in the front of the body. Thus, when choosing and using antibacterial drugs for the treatment of infectious diseases of reptiles should take into account a number of morpho-functional features of reptiles, sensitivity of microorganisms to antibiotics, choose the right dose, frequency, method and place of administration, consider the possibility of complications.

Key words: reptiles, antibiotics, portal venous system of kidneys, bacterial infections of reptiles.

\section{Особливості застосування антибіотиків у герпетології}

\author{
В. I. Чулюк
}

Львівський національний університет ветеринарної медицини та біотехнологій імені С. 3. Гюицького, м. Львів, Украӥна

У статті узагальнено літературні дані щодо частоти виникнення та причин захворювань рептилій, особливостей інфікування їх бактеріальними мікроорганізмами, застосування протимікробних препаратів та розвиток антибіотикорезистентності. Варто зазначити, щз застосування антибіотиків та інших антимікробних препаратів у ветеринарній герпетології має свої особливості, що зумовлено насамперед особливостями терморегуляиї та метаболізму у плазунів, характером патогенної 
мікрофлори, яка властива ичим тваринам. У плазунів частіше спостерігається інфікування грамнегативними мікроорганізмами: ентеробактеріями (сальмонелами, кишковими паличками, протеєм) та грампозитивними бактеріями (стафіло- та стрептококами), а також сапрофітами, що належать до групи спороутворюючих мікроорганізмів. Досить виражену патогенну активність виявляють також деякі види актиноміцетів. Нерідко у рептилій реєструється сальмонельоз. Також спостерігається сальмонелоносійство. У таких випадках створюються умови для потениійного зараження сальмонелами людей, найчастіше інфікуються діти та особи похилого віку, які контактують з хворими плазунами. Також небезпечними є інші антропозоонози (еширіхіози, лептоспіроз, хламідіоз, кампілобактеріоз, стрептококози, стафілококози, грибкові інфекиї тощчо). Антибіотики стали призначати хворим рептиліям ще “на початку розвитку” ветеринарної герпетології. Ефективність застосування протимікробних препаратів залежить від багатьох фаторів (виду, віку та статі рептилій, їхнього фізіологічного стану. температури тіла, інтенсивності метаболізму, наявності основного та супутніх захворювань, виду бактерій, якими інфіковані плазуни, та їхньої стійкості до атибактеріальних препаратів тощо). На відміну від ссавців, у рептилій наявна ворітна венозна система нирок, яка представлена системою вен, за допомогою чого значна частина венозної крові з задньої частини тіла потрапляє у ворітну вену нирок, щуо розпадається на систему капілярів. Ці гемокапіляри огортають ниркові канальці і беруть участь у виділенні багатьох токсичних сполук, в тому числі антибіотиків. Таким чином ворітна венозна система нирок разом з ворітною венозною системою печінки відіграють важливу роль у метаболізмі та виведенні з організму більиості антибіотиків. Враховуючи потенційну нефротоксичність антибіотиків та можливість швидкого виведення їх з організму (завдяки наявності ворітної венозної системи нирок), більшість герпетологів рекомендує проводити парентеральне введення лікарських препаратів плазунам у передню (краніальну) частину тіла. Таким чином, під час вибору та застосування антибактеріальних препаратів для лікування інфекційних захворювань плазунів слід враховувати ичілий ряд морфо-функиіональних особливостей рептилій, а також чутливість мікроорганізмів до антибіотиків, правильно обирати дози, кратність, спосіб та місце введення препаратів, враховувати можливість розвитку ускладнень.

Ключові слова: рептилї, антибіотики, Ворітна венозна система нирок, бактеріальні інфекиї плазунів.

\section{Вступ}

Рептилії - це представники окремого класу хребетних пойкілотермних тварин, які є важливою складовою багатьох екологічних систем. Екологічна та еволюційна роль цих організмів відіграла визначальну роль у походженні та подальшому розвитку птахів та ссавців. Рептилії $є$ першими хребетними тваринами, які повністю перейшли до наземного способу існування, а повернення деяких видів до водного середовища $€$ вторинним явищем. У еволюційному дереві деякі 3 плазунів (крокодили, динозаври) набагато тісніше пов'язані з птахами, ніж з іншими рептиліями (Pincheira-Donoso et al., 2013; Shine, 2013).

Рептилій досить часто вирощують в зоопарках, океанаріумах, зоокуточках, домашніх тераріумах тощо. У тварин, яких утримують в неволі, досить часто реєструються заразні захворювання. Частота виникнення інфекцій зростає у випадку постійного надходження в герпетологічні колекції тварин, які були відловлені в дикій природі. Придбані з таких колекцій рептилії можуть бути інфіковані бактеріями, мікоплазмами або хламідіями, вірусами, інвазійними агентами тощо.

Під час комплексного лікування бактеріальних та грибкових хвороб рептилій протимікробна терапія $\epsilon$ важливим та основним компонентом. Принципи терапії у рептилій значно відрізняються від медикаментозного лікування ссавців та птахів. Вибір ефективних протимікробних засобів для лікування пойкілотермних тварин, до яких належать плазуни, буває досить складним. Це пов'язано з анатомічними та фізіологічними особливостями представників різних рядів плазунів, низьким рівнем метаболізму, особливостями крово- та лімфообігу тощо (Mader \& Divers, 2014).

\section{Результати та їх обговорення}

У плазунів, як і в інших хребетних тварин, трапляються захворювання як інфекційного, так і незараз- ного генезу. Причиною загибелі 26,88 \% морських черепах, що були виловлені на узбережжі Канарських островів: довгоголової морської черепахи (Caretta caretta), зеленої черепахи (Chelonia mydas), шкірястої черепахи (Dermochelys coriacea), були пневмоніï, гепатити, менінгіти, септичні процеси та новоутворення. У 69,89 \% морських черепах виявляли загибель від уражень, що була пов'язана 3 діяльністю людини. Найчастіше траплялись: травми, спричинені кораблями і човнами $(23,66$ \%), а також спостерігали заплутування у рибальських сітках $(24,73 \%)$, проковтування рибальських гачків (19,35\%), заковтування сирої нафти (2,15\%). Травматичні виразкові дефекти шкіри були найпоширенішими зовнішніми ушкодженнями, які траплялись у 39,78 \% обстежених морських черепах. Зазвичай такі пошкодження шкіри супроводжувались інфікуванням Aeromonas hydrophila, Vibrio alginolyticus та Staphylococcus spp. Також під час розтину морських черепах виявляли набряк легень $(15,05 \%)$, гранулематозну пневмонію $(12,90 \%)$, ексудативну бронхопневмонію (7,53 \%), різноманітні види нефритів: хронічний інтерстиціальний нефрит, гранулематозний нефрит та абсцеси тканин навколо нирок (13,98 \%). В органах травлення морських черепах виявляли виразковий та фібринозний езофагіт, травматичну перфорацію стравоходу. Також виявляли личинкові стадії нематод, що належать до родини Anisakidae, які локалізувались у шлунку та спричиняли гастрит у 16,13 \% черепах. У печінці виявляли некротизуючий та гранулематозний гепатит у 27,95 \% морських черепах. Ураження очей включали гетерофільний кератокон'юнктивіт, виразковий кератит та гетерофільний склерит, що виявили у 7,53 \% морських черепах (Orós et al., 2005).

За даними (Robinson et al., 2015) дослідження рівня летальності рептилій, що були відловлені з природних ареалів і утримувались в герпетологічній колекції Кемптон-Парку в Лондоні та колекції герпетологічного товариства на іподромі Донкастер, встановили, що 3,6 \% рептилій загинули впродовж одного року з 
моменту придбання. В удавів та пітонів рівень смертності був найнижчим і складав $1,9 \%$, а у хамелеонів найвищими - 28,2 \%.

У великих колекціях зоопарків захворювання бактеріальної етіології призводять до загибелі рептилій у 36 \% випадків (Vasil'ev, 2012).

Найчастіше у рептилій розвиваються інфекції, що спричинені грам-негативними бактеріями. Від здорових та хворих плазунів, яких утримують у неволі, досить часто виділяють Pseudomonas aeruginosa, Aeromonas hydrophila, Providencia rettgeri, Morganella morganii, Salmonella arizonae, Serratia spp. та Klebsiella oxytoca (Isaza \& Jacobson, 2013). Зазвичай ці бактерії виявляють виражену патогенну дію за умов зниження резистентності, що розвивається внаслідок впливу на макроорганізм різноманітних факторів.

Відловлені з природних біотопів рептилії зазвичай інфіковані умовно-патогенними або патогенними мікроорганізмами. За даними (Bannai et al., 2017) у Тріонікса євфратського (Rafetus euphraticus Gray, 1864), відловленого у болотах (маршах) східної частини Хаммара в Іраку, 40 \% черепах виявились інфікованими Echerihia coli та Pseudomonas aeruginosa.

Бактерії, особливо грамнегативні, які зазвичай виділяють у плазунів із гострими або хронічними респіраторними захворюваннями, часто $є$ умовно- патогенними. Однак у рептилій нерідко виявляють зниження функції імунної системи. В таких умовах зазначені мікроорганізми можуть стати первинними патогенами та спричинити розвиток бактеріальних інфекцій (Tul \& Skrypka, 2016).

За хронічних запальних процесів верхніх дихальних шляхів пустельних черепах (Xerobates agassizii) виділяли Mycoplasma spiralis та Pasteurella testudinis (Jacobson et al., 1991).

Досить часто рептилії $є$ причиною зараження людей патогенними бактеріями, в тому числі сальмонелами. Зокрема, черепахи нерідко є резервуаром сальмонел. Це може становити загрозу для здоров'я людей, особливо для немовлят, дітей та людей похилого віку (Zancolli et al., 2015; Wang et al., 2020; Sodagari et al., 2020).

Найчастішими патологічними станами, які трапляються у черепах, є: абсцес, пневмонія, риніт, вірусні інфекції, неспецифічна бактеріальна пневмонія, випадіння клоаки або прямої кишки, гельмінтози, дерматомікози, кон'юнктивіти, затримка відкладання яєць, мальадаптативний синдром, рахіт, некроз панцира, остеомієліт панцира, остеопороз, паракератоз сухопутних черепах, панофтальміт, набрякання очей, переломи, сальмонельоз, системні мікози, поноси, запори, хронічний гастрит, лущення шкіри, виразковий стоматит (Jarofke \& Lande, 2012).

Згідно $з$ даними (Işler \& Secer, 2015) у червоновухих черепах за розвитку кон'юнктивіту, що спричинений Aeromonas hydrophyla та Pseudomonas spp., у комплексній терапії, окрім місцевого використання $3 \%$ розчину борної кислоти та перорального задавання вітаміну А, застосовують ванночки 3 енрофлоксацину (5 мг/л).
Під час дослідження стану слизової оболонки носової порожнини та клоаки 70 зелених черепах (Chelonia mydas) з Національного парку Тортугеро, (Коста-Ріка) було ізольовано 325 бактеріальних груп: 239 грамнегативних бактерій та 86 грампозитивних. Найчастіше виявляли Klebsiella pneumonia, а також мікроорганізми $з$ родини Enterobacteriaceae, включаючи Enterobacter agglomerans, E. cloacae, Escherichia coli, Klebsiella oxytoca, K. pneumoniae та Serratia marcescens. Виявляти такі грампозитивні бактерії: $S$. aureus, $S$. cromogenes, $S$. epidermis та $S$. intermedius (Santoro et al., 2006).

Застосування антибіотиків та інших антимікробних препаратів для всіх плазунів має свої особливості. Це насамперед зумовлено непостійною температурою тіла у рептилій, низьким рівнем метаболізму, характером патогенної мікрофлори, що властива цим тваринам. Антибіотики стали призначати хворим рептиліям ще “на початку розвитку” ветеринарної герпетології, в кінці 60-х рр. минулого століття. Перші оглядові публікації з'явилися на початку 80 -х років $\mathrm{XX}$ століття.

Поступово кількість повідомлень щодо застосування антибіотиків у ветеринарній герпетології зростала. Дані щодо використання антибактеріальних препаратів для лікування рептилій узагальнено в таблиці 1.

У ветеринарній герпетології данофлоксацину мезилат рекомендується застосовувати в дозі 1,2515 мг/кг (Zwart, 1964). Оскільки повідомлялося, що 6 мг/кг данофлоксацину були ефективними проти різних інфекцій (Corum et al., 2019).

Загальноприйнятою $є$ рекомендація проведення тестувань антибіотикорезистентності. Стійкість до антибіотиків часто трапляється у грам-негативних бактерій, виділених від різних видів черепах. Найвищі показники резистентності виявлені до енрофлоксацину (77 \%) та ампіциліну (69,2\%). Також виявлено стійкість понад 50 \% до амоксициліну/клавуланової кислоти (62,5\%), цефтіофуру (53,8 \%) та еритроміцинy (53,3 \%) (Orós et al., 2005; Liu et al., 2013; Carini et al., 2017).

Даних щодо фармакокінетики для більшості антимікробних засобів, що використовуються для лікування бактеріальних інфекцій у плазунів, не вистачає, а терапевтичні ефекти вивчені недостатньо. У багатьох випадках антибіотики широкого спектру дії ефективні до відомих збудників бактерій.

Більшість бактерій, виділених із організму плазунів із хворобами органів дихання, є грам-негативними і досить часто трапляються у навколишньому середовищі. Бактерії, які вдалося виділити з організму плазунів, включали: Klebsiella spp., Proteus spp., Aeromonas spp., Salmonella spp. та Staphylococcus spp., Pasteurella testudines були ізольовані від пустельних черепах (Gopherus agassizii) iз запаленням легенів. Анаеробні інфекції рідко асоціюються із захворюваннями органів дихання, хоча Fusobacterium spp, Clostridium spp та Bacteroides spp нерідко виділяють від плазунів (Schumacher, 2003). 


\section{Таблищя 1}

Основні антибактеріальні та протигрибкові препарати, що використовуються для рептилій (за Якобсеном (2012) та за Васильєвим (2012)

\begin{tabular}{|c|c|c|}
\hline Назва препарату & Доза, спосіб і кратність введення & Показання, особливості застосування тощо \\
\hline Амікацин & 5-10 мг/кг, в/м, кожні 48 год & $\begin{array}{l}\text { дерматит, підшкірні абсцеси, стоматит, пневмонія, } \\
\text { септицемія, абсцеси, кон'юнктивіт. Необхідна регід- } \\
\text { ратація }\end{array}$ \\
\hline Амоксицилін & 22 мг/кг, кожні 12-24 год & кишкові інфекції \\
\hline Ампіцилін (натрієва сіль) & 50-100 мг/кг, в/м, кожні 24 год & епідерміт/дерматит \\
\hline Гентаміцин & $\begin{array}{l}10 \text { мг/кг, в/м, кожні } 48 \text { год } \\
6-7,5 \text { мг/кг, в/м кожні } 72 \text { год; } \\
0,3 \% \text { очні каплі }\end{array}$ & $\begin{array}{l}\text { кон'юнктивіт, увеїт } \\
\text { сухопутні черепахи, водні черепахи }\end{array}$ \\
\hline Доксоциклін & 10 мг/кг, п/о, кожні 24 год & стійкі інфекції \\
\hline Кліндаміцин & 5 мг/кг, п/о, кожні 24 год & виразковий дерматит \\
\hline Левоміцитин-сукцинат & $\begin{array}{l}50 \text { мг/кг, п/к, кожні } 24 \text { год } \\
6 \text { мг/кг, в/м, кожні } 12 \text { год }\end{array}$ & $\begin{array}{l}\text { інфекції органів сечової системи, органів травлення, } \\
\text { сухопутні черепахи, водні черепахи }\end{array}$ \\
\hline Окситетрацеклін & 50 мг/кг, в/м, кожні 24 год & респіраторні інфекції \\
\hline Метронідазол & 20 мг/кг, п/о, кожні 24 год & анаеробні інфекції \\
\hline $\begin{array}{l}\text { Пеніцилін (бензинпеніцилін } \\
\text { натрієва сіль) }\end{array}$ & $200-400$ мг/кг, в/м, кожні 24 год & $\begin{array}{l}3 \text { аміноглікозидами, } \\
\text { грампозитивні бактерії }\end{array}$ \\
\hline Сульфацил-натрій & $\begin{array}{l}10-15 \% \text { розчин, під нижню } \\
\text { повіку, кожні } 12 \text { год }\end{array}$ & кон'юнктивіти \\
\hline Тилозин & 50 мг/кг, в/м, кожні 48 год & мікоплазмозний риніт \\
\hline Хлоргексидин & $0,5 \%$ водний $\mathrm{p}-\mathrm{H}$ & інфіковані рани, пневмонія \\
\hline Цефалексин & 20-40 мг/кг, п/о, кожні 12 год & сепсис \\
\hline Ципрофлоксацин & 10 м/г, п/о, кожні 48 год & сепсис \\
\hline
\end{tabular}

Більшість антибіотиків виводяться з організму завдяки роботі нирок і володіють вираженою нефротоксичною дією (Montali et al., 1979).

Нирки рептилій метанефричного типу, розташовуються в задній частині целому, а в деяких видів локалізуються у порожнині малого тазу. У більшості видів ящірок краніальний кінець нирок лежить попереду клоаки, тимчасом як каудальна частина досягає хвостових м'язів. Нирки у плазунів червонокоричневого або червоно-коричнево-жовтого кольору. У переважної більшості змій нирки видовжені, розташовуються в каудальній частині целому, розташовані асиметрично, прикріплені за допомогою короткої брижі, розділені на дрібні часточки. Нирки черепах розташовуються вентро-каудально, в межах тазу, перебуваючи в тісному зв'язку з карапаксом, межують 3 каудальною частиною легень. Ниркова миска у рептилій відсутня. Макроскопічного поділу на кіркову та мозкову речовину прослідкувати не вдається. Нефрони більшості рептилій розпочинаються нирковим тільцем, що включає примітивно побудоване артеріальне сплетіння капілярів, оточене двостінною капсулою Шумлянського-Боумена. Від ниркового тільця відходять проксимальні звивисті канальці. Петля Генле у рептилій відсутня. Дистальні канальці несуть сечу в збірні ниркові канальці (Zwart, 1964; Dantzler \& Braun, 1980; Holz \& Barker, 2012; Yari \& Gharzi, 2013; Ahmed \& Rasha, 2013).

Функція нирок у рептилій включає осморегуляцію, підтримання водного та кислотно-лужного балансу, виділення метаболітів, в тому числі продуктів обміну білків, продукцію гормонів, еритропоетину, синтез вітаміну C, активацію вітаміну D (Wyneken \& Made, 2002).
У рептилій, як і в більшості видів риб, амфібій та птахів, наявна ворітна венозна система нирок, завдяки якій значна частина венозної крові, що відтікає від хвоста та тазових кінцівок, потрапляє у нирки. Ворітна система нирок присутня у всіх плазунів (Holz, 2020). Деяка частина крові $з$ каудальної частини тіла потрапляє у ворітну венозну систему печінки, оминаючи нирки (Holz et al., 1998; Wyneken \& Made, 2002).

У зв'язку з наявністю ворітної венозної системи нирок та нефротоксичністю антибіотиків, переважна більшість ветеринарних герпетологів акцентує увагу на тому, що парентеральне введення лікарських препаратів рептиліям краще проводити в передню (краніальну) частину тіла (Holz et al., 1997; Dustin et al., 2018).

\section{Висновки}

Проаналізувавши літературні дані щодо особливостей розвитку інфекційних хвороб та застосування антибактеріальних препаратів у рептилій, варто зробити висновок, що під час проведення терапевтичних процедур необхідно враховувати морфофункціональні особливості плазунів, які належать до пойкілотермних хребетних тварин, температура тіла та швидкість обміну речовин яких залежать від температури навколишнього середовища. У зв'язку з наявністю у плазунів ворітної венозної системи нирок парентеральне введення антибіотиків краще проводити у передню (краніальну) частину тіла. Не варто використовувати дозування антибіотиків, що визначені для ссавців і птахів, а необхідно використовувати дози антибактеріальних препаратів, які були встановлені для плазунів. 


\section{References}

Ahmed, A., \& Rasha, E. (2013). Comparative histological, histochemical and ultrastructural studiesof the nephron of selected snakes from the Egyptian area. Biologia, 68/3, 546-558. doi: 10.2478/s11756-013-0181-7.

Bannai, M., Mohammad, E., Shamary, A., Najjar, K., \& Al-Khwaja, F. (2017). Contribution and pathology of e. Coli and pseudomonas aeruginosa bacterial infection on soft shell turtle rafetus euphraticus (gray, 1864) east hammar marshes, IRAQ. Ruussian journal of parasathology, 40(2), 174-178.

Carini, A., Ariel, E., Picard, J., \& Elliott, L. (2017). Antibiotic Resistant Bacterial Isolates from Captive Green Turtles and In Vitro Sensitivity to Bacteriophages. International Journal of Microbiology. doi: 10.1155/2017/5798161.

Corum, O., Corum, D., Altan, F., Ee, A., Centin, G., \& Uney, K. (2019). Pharmacokinetics of intravenous and intramuscular danofloxacin in red-eared slider turtles (Trachemys scripta elegans) J. Vet. Med. Sci., 81(5),753-757. doi: 10.1292/jvms.18-0609.

Dantzler, W., \& Braun, E. (1980). Comparative nephron function in reptiles, birds, and mammals. American Journal of Physiology-Regulatory, 239(3), 197-213. doi: 10.1152/ajpregu.1980.239.3.R197.

Dustin, M., Grayson, A., Kurt, K., \& Christoph, M. (2018). Effect of injection site on dexmedetomidineketamine induced sedation in leopard geckos (Eublepharis macularius). Journal of the American Veterinary Medical Association. 253(9), 1146-1150. doi: 10.2460/javma.253.9.1146.

Holz, P. (2020). Anatomy and Physiology of the Reptile Renal System. Vet Clin North Am Exot Anim Pract, 23(1), 103-114. doi: 10.1016/j.cvex.2019.08.005.

Holz, P., \& Barker, I. (2012). Reptiles. Diagnostic Pathology ofthe Diseases of Aquatic, Aerial and Terrestrial Wildlife, Australian Registry of WildlifeHealth, Sydney, NSW, 50-62.

Holz, P., Barker, I., Crawshaw, G., \& Dobson, H. (1998). The anatomy and perfusion of the renal portal system in the red-eared slider (trachemys scripta elegans). Journal of Zoo and Wildlife Medicine, 28(4), 378 385. URL: https://pubmed.ncbi.nlm.nih.gov/9523630.

Holz, P., Barker, K., Burger, J., Crawshaw, J., \& Peter, D. (1997). The Effect of the Renal Portal System on Pharmacokinetic Parameters in the Red-Eared Slider (Trachemys scripta elegans). Journal of Zoo and Wildlife Medicine, 28(8), 386-393. URL: https://pubmed.ncbi.nlm.nih.gov/9523631.

Isaza, R., \& Jacobson, E. (2013). Antimicrobial Drug Use in Reptiles. Antimicrobial Therapy in Veterinary Medicine. doi: 10.1002/9781118675014.ch37.

Işler, C., \& Secer, F. (2015). Treatment of Bath with Enrofloxacin in Red-Eared Sliders (Trachemys scripta elegans) Suffer from Conjunctivitis and Its Results. Kafkas Univ Vet FakDerg, 21(3), 429-431. doi: 10.9775/kvfd.2014.12621.

Jacobson, E., MGaskin, J., Brown, M., Harris, R., Gardiner, C., LaPointe, J., Adams, H., \& Reggiardo,
C. (1991). Chronic upper respiratory tract disease of free-ranging desert tortoises (Xerobates agassizii). J Wildl Dis., 2, 296-316. doi: 10.7589/0090-355827.2.296.

Jarofke, D., \& Lande, Ju. (2012). Reptilii bolezni i lechenie. Moskva: AKVARIUM-PRINT (in Russian).

Liu, D., Wilson, C., Hearlson, J., Singleton, J., Thomas, R., \& Crupper, S. (2013). Prevalence of antibiotic-resistant Gram-negative bacteria associated with the red-eared slider (Trachemys scripta elegans). J ZooWildlMed, 44(3), 666-671. doi: 10.1638/2012-0252R1.1.

Mader, D., \& Divers, S. (2014). Divers Current Therapy in Reptile Medicine and Surgery. URL: https:/www.sciencedirect.com/book/9781455708932/ current-therapy-in-reptile-medicine-and-surgery.

Montali, R., Bush, M., \& Smeller, J. (1979). The Pathology of Nephrotoxicity of Gentamicin in Snakes. Vet. Pathol., 16(1), 108-115. doi: 10.1177/030098587901600111.

Orós, J., Torrent, A., Calabuig, P., \& Déniz, S. (2005). Diseases and causes of mortality among sea turtles stranded in the Canary Islands, Spain (1998-2001). Dis Aquat Organ, 63(1), 13-24. doi: 10.3354/dao0630132005.

Pincheira-Donoso, D., Bauer, A., Meiri, S., \& Uetz, P. (2013). Global Taxonomic Diversity of Living Reptiles. PLOS ONE, 1-10. doi: 10.1371/journal.pone.0059741.

Robinson, E., Freya A., Richard, A., \& Roberts, G. (2015). Captive Reptile Mortality Rates in the Home and Implications for the Wildlife Trade. PLOS ONE, 1-14. doi: 10.1371/journal.pone.0141460.

Santoro, M., Hernández, G., \& Caballero, M. (2006). Aerobic bacterial flora of nesting green turtles (Chelonia mydas) from Tortuguero National Park, Costa Rica. J Zoo Wildl Med., 37(4), 549-552. doi: 10.1638/05-118.1.

Schumacher, J. (2003). Reptile respiratory medicine. Vet Clin North Am Exot Anim Pract, 6(1), 213-231. doi: 10.1016/s1094-9194(02)00020-8.

Shine, R. (2013). Reptiles. Curr Biol., 23(6), R227-R231. doi: 10.1016/j.cub.2013.02.024.

Sodagari, H., Habib, I., Shahabi, M., Dybing, N., Wang, P., \& Bruce, M. (2020). A Review of the Public Health Challenges of Salmonella and Turtles. VetSci., 7(2), 56. doi: 10.3390/vetsci7020056.

Tul, O. I., \& Skrypka, M. V. (2016). Rezultaty mikrobiolohichnoho skryninhu bakterialnykh asotsiatsii yashchirky prudkoi na terytorii m. Poltava. Problemy zooinzhenerii ta veterynarnoi medytsyny, 33(2), 113-118 (in Ukrainian).

Vasil'ev, D. B. (2012). Cherepahi soderzhanie, bolezni i lechenie. Moskva: AKVARIUM-PRINT (in Russian).

Wang, W., Fang, H., Cui, Q., Ye, C., Gui, Y., Su, J., \& Hao, L. (2020). First report of Salmonella Pomona infection in a young child associated with pet turtle exposure in Shanghai. Disease Surveillance, 35(10), 957-960. doi: 10.3784/j.issn.1003-9961.2020.10.018.

Wyneken, J., \& Made, D. (2002). Anatomy and clinical applications of the renal portal system and the ventral abdominal vein in reptiles. Association of Reptilian and Amphibian Veterinarians, 183-186. URL: 
https://cdn.ymaws.com/members.arav.org/resource/res mgr/Files/Proceedings 2002/2002 50.pdf.

Yari, A., \& Gharzi, A. (2013). Anatomical and Histological Study of the Excretory System in the Bosc's Fringe-Toed Lizard (Acanthodactylus boskianus). Asian Journal of Animal Sciences, 7, 3035. doi: 10.3923/ajas.2013.30.35.
Zancolli, G., Mahsberg, D., Sickel, W., \& Keller, A. (2015). Reptiles as Reservoirs of Bacterial Infections: Real Threat or Methodological Bias? Microb Ecol., 70(3), 579-584. doi: 10.1007/s00248-015-0618-3.

Zwart, P. (1964). Studies on Renal Pathology in Reptiles. ZWART Studies on Renal Pathology in Reptiles, 542556. 